\title{
A Tiny Paradise of Nature
}

If we listen to the innermost recesses of the heart, we discover the strange fact that we are not only married to our human partner, but to a remarkable degree also to the environment which intimately surrounds us. Our garden, for instance, is often the mirror of ourselves! The way we treat it and use it - lovingly or indifferently - or even abuse it with no regard or respect. The observed association of course varies: some of us seem to be quite happy and well-balanced, some others are less so, while many are restless and always running after new and exciting adventures. On Sundays these people often leave their homes, seeking 'real Nature' elsewhere. Yet a correctlyplanned wild garden populated with native plants is never boring! It commonly develops not only a very rich flora, but also often an unbelievable variety of associated fauna.

When I started my 'private project of wilderness' on our lot (about $6,000 \mathrm{~m}^{2}$ ) I was absolutely alone with this idea: nobody wanted to help me or even accept my 'foolish thoughts'. At that time, my otherwise so nice and understanding husband did not agree with such 'nonsense'. Yet today he fights on my side against environmental destruction of any kind. Twenty-five years ago the idea of 'wilderness' around one's house was brand-new and indeed revolutionary. For in Switzerland, environmental protection activities were regarded as having an extremely 'left-wing political touch', though I cannot imagine why. So rejection was commonly the reaction of neighbours. And then there was the big fright of 'contamination' by the weed seedlings. Even in these days, a neighbour (a physician) is lodging a legal complaint about our hedge which he does not want to see any more - not because it takes away the sunlight, or the view, or causes any damage. No, it seems to be just a whim, or mere anti-innovationism. So probably the fight for a more natural and healthy environment will never end.

My concrete plan was to create a forest-glade with several ponds in a romantic wilderness of native trees, bushes, weeds, grass, and flowers. The start was not easy. The very loamy soil was badly over-fertilized with artificial manure, and polluted with herbicides and pesticides etc. A farmer of the old generation had been the former owner of our abused spot of land. But even with a more or less healthy soil and better preconditions than I had, a lot of time and patience would have been needed to recreate the conditions for native, natural fauna and flora to thrive.
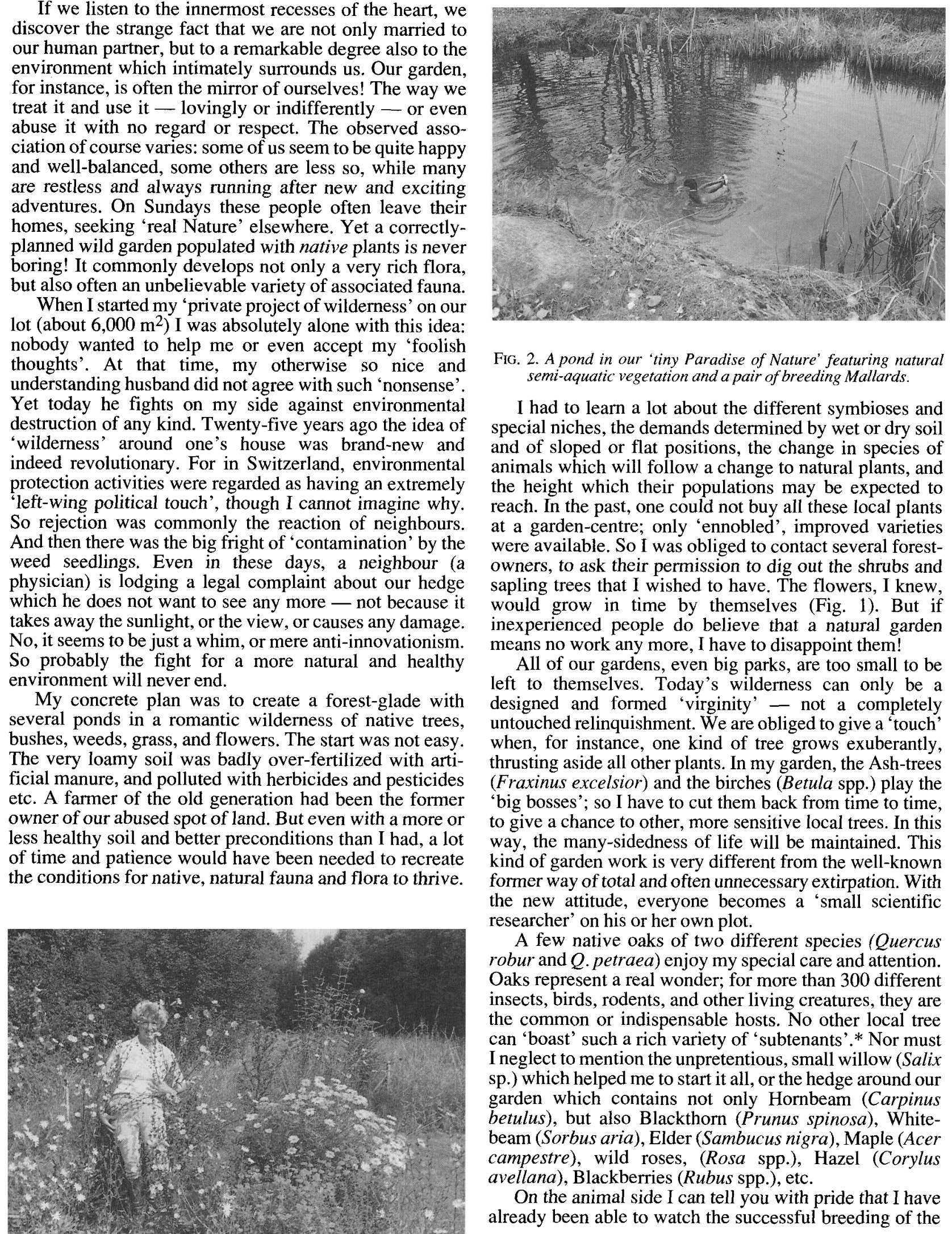

FIG. 2. A pond in our 'tiny Paradise of Nature' featuring natural semi-aquatic vegetation and a pair of breeding Mallards.

I had to learn a lot about the different symbioses and special niches, the demands determined by wet or dry soil and of sloped or flat positions, the change in species of animals which will follow a change to natural plants, and the height which their populations may be expected to reach. In the past, one could not buy all these local plants at a garden-centre; only 'ennobled', improved varieties were available. So I was obliged to contact several forestowners, to ask their permission to dig out the shrubs and sapling trees that I wished to have. The flowers, I knew, would grow in time by themselves (Fig. 1). But if inexperienced people do believe that a natural garden means no work any more, I have to disappoint them!

All of our gardens, even big parks, are too small to be left to themselves. Today's wilderness can only be a designed and formed 'virginity' - not a completely untouched relinquishment. We are obliged to give a 'touch' when, for instance, one kind of tree grows exuberantly, thrusting aside all other plants. In my garden, the Ash-trees (Fraxinus excelsior) and the birches (Betula spp.) play the 'big bosses'; so I have to cut them back from time to time, to give a chance to other, more sensitive local trees. In this way, the many-sidedness of life will be maintained. This kind of garden work is very different from the well-known former way of total and often unnecessary extirpation. With the new attitude, everyone becomes a 'small scientific researcher' on his or her own plot.

A few native oaks of two different species (Quercus robur and $Q$.petraea) enjoy my special care and attention. Oaks represent a real wonder; for more than 300 different insects, birds, rodents, and other living creatures, they are the common or indispensable hosts. No other local tree can 'boast' such a rich variety of 'subtenants'.* Nor must I neglect to mention the unpretentious, small willow (Salix sp.) which helped me to start it all, or the hedge around our garden which contains not only Hornbeam (Carpinus betulus), but also Blackthorn (Prunus spinosa), Whitebeam (Sorbus aria), Elder (Sambucus nigra), Maple (Acer campestre), wild roses, (Rosa spp.), Hazel (Corylus avellana), Blackberries (Rubus spp.), etc.

On the animal side I can tell you with pride that I have already been able to watch the successful breeding of the

FIG. 1. The Authoress among her 'most-loved weeds.'

* The Beech (Fagus sylvatica) ranks next with more then 200 'subtenants'. 
Tawny Owl (Strix aluco), of wild Mallards (Anas platyrhyncos) Fig. 2), of four different kinds of woodpeckers (Picidae), of the Spotted Flycatcher (Muscicapra striata), the Common Dormouse (Muscardinus avellanarius), the Frog (Rana temporaria), the Toad (Bufo vulgaris), the Slow-worm (Anguis fragilis), the Common Newt (Triturus vulgaris), and many, many more. As irregular guests I have noted the Woodcock (Scolopax rusticola), the Hoopoe (Upupa epops), a species of Kite and two different ones of falcons, and the common Quail
(Coturnix coturnix); more often the Red Fox (Vulpes vulpes), squirrels (Sciuridae), roe deer (Caprellus sp.), the Buzzard (Buteo buteo), the Hare (Lepus europaeus), the Marten (Martes martes), and a lot of butterflies and bumble-bees - all in the suburb of our provincial town of Burgdorf!

JEANETTE DÜR-LINDT Merianweg 28 CH-3400 Burgdorf Switzerland.

\section{The St Sorny Nature Demonstration Reserve in Southern France}

St Sorny is situated in the hills of north Ardèche, near the west bank of the Rhône, approximately $25 \mathrm{~km}$ south of Tournon. It is a small, long-preserved estate, very quiet and secluded, consisting of a complex of old buildings half farm and half hermitage, with a small disused chapel (Fig. 1) - all lying near a curve of a tributary river of the Rhône. It is surrounded by unspoiled hills and its tranquil atmosphere invites peaceful meditation as well as research and demonstration.

The estate - of some 20 hectares - is largely of rather open and low forest of variable composition but in places dominated by coniferous or Sweet Chestnut (Castanea vulgaris) trees, with entry of many southern maquis plants. It was acquired in 1965 by three like-minded friends: Didier Roux, of a Geneva family, who has devoted his life to education and social work; Bernard Sartorius, from an old Basle family, who is a psychologist but widely concerned with environmental preservation; and Alfred Necker, doctor of laws and notary in Geneva, who has also devoted much of his spare time to conservation and forestry. The three friends together created a small French holding company: the Société Civile de Saint-Sorny.

Now, 26 years later, the above-mentioned three friends ardently wish that their efforts to preserve St Sorny be perpetuated, and are concerned about its future. They remain committed to their task of maintaining the entire estate of St Sorny, but in the past few years have transferred its management to an association, 'Friends of St Sorny' (ASSY), of which the Chairman, a schoolmaster from Geneva, and his wife and young family, are among its most frequent visitors-and-more, being indeed part-time residents. Although the three friends are still the owners of the estate and remain in control, they are not generally involved in the details of management; they do, however, assist in taking major decisions concerning the use and management of the estate.

There has been some question of transferring the title of the estate to ASSY. After serious reflection, however, the owners realize that they do not wish to transfer the title to the orgainzation of beneficiaries of the place, because they fear that members of the organization might, at some future time, change the purposes and use of St Sorny. So their intention now is to transfer the title of ownership of the Société Civile de Saint-Sorny to an impersonal and immortal, permanent Trustee, which would assure the continuance of the founders' original aims: conservation and appropriate use of the estate for peaceful purposes, including research and Nature demonstration. The beneficiary in coming years would be the ASSY; but should it disappear, or its members chart a new course for, or misuse of, St Sorny, the Trustee would have the right and duty to seek other beneficiaries who would adhere to the aims of the founders.

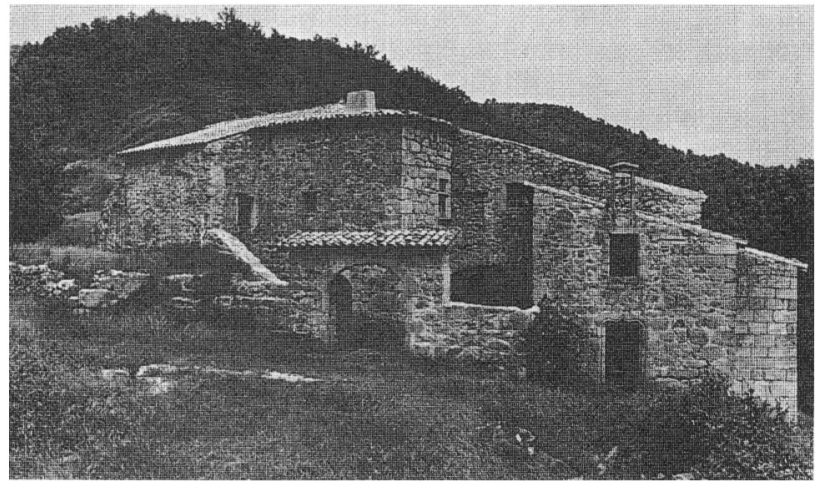

FIG. 1. The main buildings of St Sorny, with the entrance to the disused chapel on the right. The roofs are everywhere sound and professionally supervised at least twice-yearly, and there is rubbermattress sleeping provision on wooden floors for about 30 boyscouts, girlguides, or schoolchildren.

At present, without any advertisement or ad hoc organization, the buildings of St Sorny are occupied during about 130 nights of each year, especially by young people and their supervisors, the total occupancy being well over 1,000 individual nights yearly. It is confidently to be expected that, through due liaison with appropriate international bodies especially in France, Switzerland, and England, the former figure could easily be extended and the latter one multiplied without harm to the Reserve.

In addition to the Trustee, there would be need of 'Protectors', who would consult with the Trustee and keep it informed. The first protectors would be the three founders and former owners, and, after them, either representative(s) of their choosing or else their legal heir(s). They should receive an annual report from the Beneficiaries, with three copies to the Trustee. At least two of the Protectors should visit the Reserve in each year, whenever possible collaborating with the Beneficiaries in preparing their report to the Trustee.

It is thought that, if the above circumstances can be established and the present friendly relations maintained with the local populace, St Sorny has every chance of becoming a model of the kind of small Nature demonstration reserve that will be needed world-wide if modern Humankind is to continue in equable occupation of The Biosphere.

\section{ALFRED NECKER \\ 5 Rue Toepffer \\ I206 Geneva \\ Switzerland}

$\&$

NichOLAS POLUNIN. 